\title{
Cortical arousal and central nervous system fatigue after a mountain marathon
}

\author{
Activación cortical y fatiga del sistema nervioso después de una maratón de montaña \\ Vicente Javier Clemente-Suárez \\ Department of Sport Science. European University of Madrid. España
}

CORRESPONDENCIA:

Vicente Javier Clemente-Suárez

Recepción: mayo 2016• Aceptación: julio 2016

vctxente@yahoo.es

\begin{abstract}
Ultraendurance research has focused on the study of physiological parameters and body composition. The study of the influence on cognitive function and central nervous system (CNS) using the Critical Flicker Fusion Threshold (CFFT) has not been measured in this event. The objective of this study was to analyzed changes in CFFT before and after a mountain marathon. We analysed 26 athletes ( 22 men and 4 women, $66.9 \pm 10.0$ $\mathrm{kg}, 171.4 \pm 7.1 \mathrm{~cm}, 37.8 \pm 9.9$ years). Before and after the event the mountain marathon runners performed a CFFT test, and for every test each subject performed the CFFT test three times. In addition, blood lactate concentration was analysed before and after the race as well as measuring heart rate during the race. The results found that the CFFT decreased after the event, with non-significance shown $(p<0.05)$. The mean heart rate was $150.9 \pm 7.9 \mathrm{bpm}$ and final lactate concentration was $4.5 \pm 1.2 \mathrm{mmol} / \mathrm{l}$. The mountain marathon event was not therefore, found to affect the CNS, fatigue was caused by other peripheral causes.
\end{abstract}

Key words: Critical flicker fusion threshold, marathon, lactate, ultraendurance.

\section{Resumen}

La investigación en pruebas de ultra resistencia se ha centrado en el estudio de parámetros fisiológicos y la composición corporal. El estudio de la influencia sobre la función cognitiva y el sistema nervioso central (SNC), utilizando el umbral de frecuencia crítica de fusión (UFCF), no ha sido medido en estas pruebas. El objetivo de este estudio fue analizar los cambios en el UFCF antes y después de una maratón de montaña. Se analizaron 26 atletas ( 22 hombres y 4 mujeres, $66.9 \pm 10.0 \mathrm{~kg}, 171.4 \pm 7.1 \mathrm{~cm}, 37.8 \pm 9.9$ años). Antes y después del maratón de montaña los corredores realizaron una prueba para analizar el UFCF, también se analizó la concentración de lactato en sangre antes y después de la carrera y la frecuencia cardíaca durante la carrera. Los resultados muestran que el UFCF disminuyó no significativamente $(p<0.05)$ después de la maratón de montaña. La media de la frecuencia cardíaca fue de $150.9 \pm 7.9$ lpm y la concentración de lactato sanguíneo final fue de $4.5 \pm 1.2 \mathrm{mmol} /$ l. Una maratón de montaña no afectó negativamente al sistema nervioso central, la fatiga fue causada por otras causas periféricas.

Palabras clave: Umbral de frecuencia crítica de fusión, maratón, lactato, ultraresistencia. 


\section{Introduction}

The study of the origin of fatigue has been a topic widely studied (Davis \& Bailey, 1997; Glaister, 2005; Lamber, Gibson, \& Noakes, 2005), although not yet fully understood processes and production mechanisms of fatigue in sports activities. Specifically, researches in ultraendurance event have been focused mainly on the study of organic response of participants. In this way, many authors have studied changes in body composition (Bircher, Enggist, Jehle, \& Knechtle, 2006; Knechtle, Fraire, Andonie, \& Kholer, 2008), muscle breakdown (Clemente et al., 2011b), autonomic modulation (Clemente-Suarez, 2014a, 2014b) energy substrates consumption (Callow, Monton, \& Guppy, 1986) and changes of various physiological parameters as urea, haemoglobin, lactate or glucose (Clemente, Navarro, \& González, 2011c; Suárez, 2011; Sulzer, Schwellnus, \& Noakes, 2005).

Research in the area of fatigue has focused primarily on peripheral fatigue, which involves reductions in the ability of muscle to perform work because of impairments anywhere along the chain of command from neuromuscular transmission to actinmyosin crossbridging (Davis \& Fitts, 1998). However, the stimulus for muscular contraction is initiated in the brain, and therefore central fatigue may occur if alterations in the central nervous system (CNS) decrease the ability to voluntarily send a signal to the neuromuscular junction (Davis \& Baley, 1996). Strategies designed to offset peripheral fatigue and enhance physical performance most often involve alterations in training and nutrition (Coyle, 1997). However, little is known about these issues regarding central fatigue. One of the causes of decreased performance in athletes is $\mathrm{fa}$ tigue of CNS (Tomporowski, 2003). The influence of physical effort in fatigue of CNS is an area little studied. One of the methods frequently used to measure fatigue of CNS and cognitive function is critical flicker fusion threshold (CFFT). The utility of CFFT in sport has been focused in the relationship of arousal level with CNS (Gortelmeyer \& Wiemann, 1982; Simonson \& Brožek, 1952). Increase in CFFT suggests an increase in cortical arousal and sensory sensitivity. By contrast, a decrease of CFFT suggests a reduction in the efficiency of the system to process information (Li, Jiao, Chen, \& Wang, 2004) and it is related with fatigue of CNS, so, if CFFT values fall below the baseline means that there is symptom of fatigue of CNS (Costa, 1993; Saito, 1992).

CFFT was affected by non sensory and sensory factors. The results must be interpreted taking into account two different parameters. The parameter re- lationship whit sensory factor was subjective criterion (CS), which reflects the response criterion. This response can be conservative or liberal. The parameter relationship whit non sensory factor was sensory sensitivity (SS). In methods will explain the form to calculate this parameter (Davranche \& Pichon, 2005). Several authors studied the CFFT in different sports stimulus. There were analyzed incremental $\mathrm{VO}_{2} \max$ test (Clemente, Martínez, Muñoz, \& González, 2010; Davranche \& Pichon, 2005), 30 min maximum cycling trial (Clemente, 2010), $70 \%$ of $\mathrm{VO}_{2}$ max cycling trial (Prestland, Dowson, \& Cirns, 2005) or RSA (repeated sprint ability) maximum speed test (Clemente, Muñoz, \& Melús, 2011a). Only in RSA speed test a decreased in CFFT was measured by contrast the other stimulus increased the CFFT. Specifically in ultraendurance event, we just found the study of Clemente \& Martinez (2010) realized in a $270 \mathrm{~km}$ ultraendurance event run relay, in while the subjects increased CFFT. In contrast, Godefroy, Rousseu, Vercruyssen, Cremieux, \& Brisswalter (2002) and Douchamps-Riboux, Heinz, \& Douchamps (1989) monitored a decrease in CFFT after performed a cycling test to exhaustion in triathletes and after performed a marathon race in rowers respectively. These contradictory results show depending the duration of the event the cortical arousal response is different.

To clarify the cortical arousal response in ultraendurance event we develop the present study with the objective of analyze the cortical arousal and CNS fatigue, through the study of CFFT, after a mountain marathon in trained athletes.

\section{Methods}

The study was carried out during the II Mountain Marathon "Pueblo de los artesanos", celebrated in Torrejoncillo (Cáceres, Spain). We analyzed 36 healthy trained runners $(66.9 \pm 10.0 \mathrm{~kg}, 171.4 \pm 7.1 \mathrm{~cm}, 37.8 \pm$ 9.9 years). They finished the mountain marathon in a mean of $229.3 \pm 49.8$ minutes. They trained a mean of $93.8 \pm 33.8$ minutes/day and $532.5 \pm 213.8$ minutes/ week, all of them did regularly exercising for more than 10 years. The mountain marathon covered the distance of $42.2 \mathrm{~km}$, whit $1070 \mathrm{~m}$ of negative elevation and $1077 \mathrm{~m}$ of positive elevation. The profile of the race is shown in Figure 1 . The temperature during the mountain marathon was between $9^{\circ} \mathrm{C}$ and $18^{\circ} \mathrm{C}$.

The CFFT measurements were carried out before and immediately after the mountain marathon. Participants were seated in front of a viewing chamber (Lafayette Instrument Flicker Fusion Control Unit Model 12021), which was constructed to control ex- 


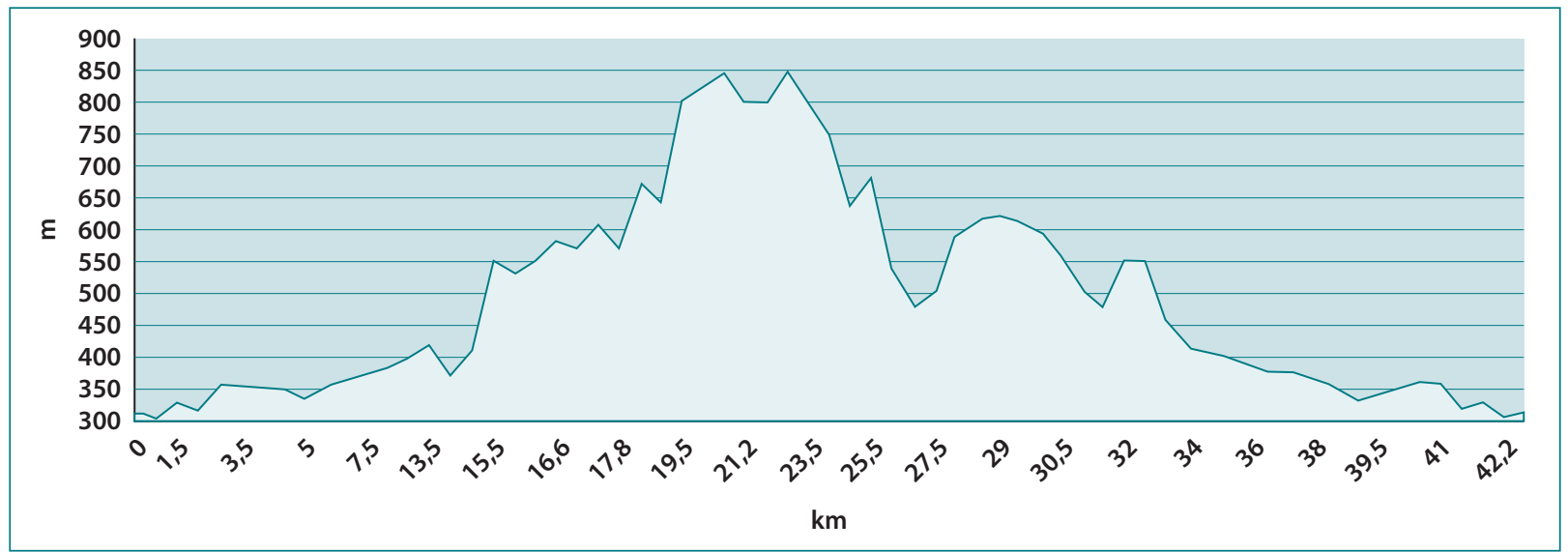

Figure 1. Profile race.

traneous factors that might distort CFFT values. Two light-emitting diodes $(58 \mathrm{~cd} / \mathrm{m} 2)$ were presented simultaneously in the viewing chamber, one for the left eye and one for the right eye. The stimuli were separated by $2.75 \mathrm{~cm}$ (center to center) with a stimulus-toeye distance of $15 \mathrm{~cm}$ and a viewing angle of $1.9^{\circ}$. The inside of the viewing chamber is painted flat black to minimize reflection. The flicker frequency increment ( $1 \mathrm{~Hz} / \mathrm{sec}$ ) changed in two ways: either it increased from 0 to $100 \mathrm{~Hz}$ until the participant perceived fusion, or it decreased from 100 to $0 \mathrm{~Hz}$ until flicker was detected. After a fovea binocular fixation, participants were required to respond by pressing a button upon identifying the visual flicker (descending frequency) and the fusion (ascending frequency) thresholds. Prior to the experiment, they performed as many practice trials as needed to become familiarization with the exigencies of the CFF test. Then, three ascending and three descending trials were performed alternatively (Clemente-Suarez \& Robles-Pérez, 2013; 2015; Dauvranche \& Pichon, 2005). Subjects carried out the test three times with an interval of 5 seconds.

In each one of the test, time was quantified as the amount of time that a subject took for detecting the changes in the lights from the beginning of the test until the moment to pressing a button, to be able to determine the CFFT:

- CFFa - (Critical Flicker Fusion ascending), average of values obtained in the ascending test.

- CFFd - (Critical Flicker Fusion descending), average of value obtained in the descending test.

- SC (Subjective Criterion), difference among the average of the values obtained in the ascending test and the average of the values obtained in the descending test.

- SS - (Sensorial Sensibility), median of the sum of the values obtained in the ascending and descending tests.
Before and after the race a blood sample was extracted from a finger on the right hand while the subject was standing with his arms flexed. A finger stick was used to collect blood lactate in a capillary tube, which was in turn placed in the Accusport Lactate Analyzer, Total Performance Inc. (Mansfield, Ohio). During the race heart rate was recorder with heart rate monitor (polar S S810. Polar Electro Ibérica. Barcelona).

The statistical analysis was carried out with the statistical program SPSS 17.0. The Shapiro-Wilk normality test was used to test homogeneity of each variable. The result shows that there were no significant differences. Student's t-test for paired observations was used for statistical evaluation of the data. The Effect Size (ES) was tested by Cohen's D [ES = (Posttest mean - Pretest mean)/Pretest SD]. For all the comparisons the index of significance accepted was $p<0.05$.

\section{Results}

The results show how the CFFa, SC and SS values decrease, in contrast to CFFd. The complete results of the different CFFT values are shown in Table 1 . During the race, athletes achieved an average heart rate of $150.9 \pm 7.9 \mathrm{bpm}$, maximal heart rate of $179.4 \pm 20.3$ $\mathrm{bpm}$ and a minimum heart rate of $120.3 \pm 9.0 \mathrm{bpm}$. The blood lactate concentration increase significantly after the mountain marathon $(2.0 \pm 0.4 \mathrm{mmol} / \mathrm{l}$ basal vs. $4.5 \pm 1.2 \mathrm{mmol} / \mathrm{l}$ after the race).

\section{Discussion}

The objective of the present research was to study the modification of CFFT after a mountain marathon in trained athletes. The decrease of SS values after the mountain marathon shows that this type of effort seems 
Table 1. Critical flicker fusion threshold results

\begin{tabular}{|c|c|c|c|c|}
\hline \multirow{2}{*}{ Umbrales Flicker Fusion } & \multicolumn{2}{|c|}{ Sample } & \multirow{2}{*}{$\%$ Change } & \multirow{2}{*}{$\begin{array}{l}\text { Effect Size } \\
\text { Cohen's D }\end{array}$} \\
\hline & Pre & Post & & \\
\hline CFFa $(\mathrm{Hz})$ & $34.69 \pm 4.03$ & $32.18 \pm 7.17$ & -7.1 & -0.62 \\
\hline CFFd $(\mathrm{Hz})$ & $31.21 \pm 7.96$ & $33.29 \pm 9.81$ & 6.7 & 0.26 \\
\hline $\mathrm{SC}(\mathrm{Hz})$ & $3.48 \pm 8.70$ & $-1.11 \pm 7.32$ & $-68.1 *$ & -0.53 \\
\hline SS (Hz) & $33.41 \pm 4.28$ & $32.73 \pm 7.77$ & -2.0 & -0.16 \\
\hline
\end{tabular}

CFFa Critical Flicker Fusion ascending; CFFd - Critical Flicker Fusion descending; SC - Subjective Criterion; SS - Sensorial Sensibility; ${ }^{*} p<0.05$ v sample Pre.

to affect negatively the cortical arousal and generate symptoms of fatigue of the CNS (Li et al., 2004). In addition, the decrease in $\mathrm{SC}$ values suggests that the change observed after mountain marathon was linked to a cautious strategy of athletes (Ghozlan \& Widlocher, 1993). The decrease in SS after the mountain marathon was also evaluated after completed a RSA (repeated sprint ability) maximum speed test (Clemente et al., 2011a), after performed an exercise cycling test to exhaustion in triathletes (Godefroy et al., 2002) and in rowers after complete a marathon race (Douchamps-Riboux, 1989). By contrast in a $\mathrm{VO}_{2}$ max cycling test (Clemente et al., 2010), 30 min maximum trial (Clemente, 2010) and after complete a $70 \% \mathrm{VO}_{2}$ max cycling trial (Presland et al., 2005) SS increased. It seems that high intensity effort with duration between 30 seconds until 30 minutes do not affect negative CNS, by contrast, sprints or ultraendurance stimulus can affect negative CNS. Possibly in mountain marathon, athletes ran until exhaustion and performed the race with the maximum velocity possible in that race, condition similar to the study of Godefroy et al. (2002). Also, the influence of dehydration, typical in marathon and mountain race (Whiting, Maughan, \& Miller, 1984) and the depletion of energy substrates, may affect negatively the SS decreasing these values (Tomporowsky, 2003). These facts could be some of the possibilities because in the present research we evaluated a decrease in SS values, as the results obtained by Godefroy et al (2002) and (Douchamps-Riboux et al., 1989). Moreover, the values of lactate and heart rate were similar to other studies in marathon (Sjödin \& Jacobs, 1981; Suárez et al., 2011) or ultraendurance run event (Clemente et al., 2011b; Suárez et al., 2011).

The cortical arousal decreased tendency observed in the present research was similar than obtained in high stress situation as combat, in which cortical arousal evaluated by the critical flicker fusion thresholds decrease (Clemente-Suárez \& Robles-Perez, 2012). Other stress situations in which a decrease in cortical arousal was evaluated were the high altitude high opening (HAHO) and high altitude low opening (HALO) parachute jumps (Clemente-Suarez, Robles-Perez, Montañez-Toledo, 2015; Clemente-Suarez, Delgado-Moreno,
Gonzalez-Gomez, \& Robles-Perez, 2015). In situation in which the perception of danger is high, the innate defence systems as fly to fight systems are activates, increasing the sympathetic modulation, having this fact a direct effect in cortical arousal. Decreased in cortical arousal seem to be linked to high sympathetic autonomous nervous system activation, when this stressor way of the autonomous nervous system is activated the cortical arousal decrease, having a direct effect on cortical function as memory (Gallego, Robles-Perez, \& Clemente-Suárez, 2013), but future research in sport activities have to confirm this theory. In this line, the availability of glucose in the brain, principal substrate that neuron process, is basic to maintain the cortical arousal and avoid CNS fatigue (Bouzier-Sore et al., 2003). This fact become more important in ultraendurance events, since the energy expenditure could duplicate the normal diary energy demands (Clemente-Suárez, 2014b).

In mountain marathon, the induced fatigue was probably a combination of different parameters as muscular damage (Ramos-Campo et al., 2016; Clemente et al., 2011b), hyponatremia (Davis et al., 2001), dehydration (Whiting et al., 1984), hyperthermia (Holtzhausen \& Noakes, 1997), substrate depletion (García-Roves, Terrados, \& Fernandez, 1998), increased sympathetic modulation (Clemente-Suarez, 2014a, 2014b) and CNS fatigue. To avoid CNS fatigue future research should.

\section{Limitation of the study and future research lines}

To know the mechanisms of fatigue in ultraendurance events future investigation should study the relationship between sympathetic nervous system activation and cortical arousal and the effect on performance. In addition, the relation between muscular activity after ultraendurance events, cortical arousal and performance should be studied. Finally, the relation between nutritional strategies during the race and the maintenance of cortical arousal should be studied in order to delimit the most effective nutritional strategies in ultraendurance events. 


\section{Conclusion}

As conclusion, the results obtained in the present research have shown the decrease of cortical arousal after performing a mountain marathon, this decrease could decrease the brain ability to voluntarily send a signal to the neuromuscular junction.

\section{Acknowledgements}

To the organization of the "Maratón de los artesanos" and the athletes that voluntary participated in the present research.

\section{REFERENCES}

Bircher, S., Enggist, A., Jehle, T., \& Knechtle, B. (2006). Effects of an extreme endurance race on energy balance and body composition - A case study. Journal of Sports Science and Medicine, 5, 154-162.

Bouzier-Sore, A. K., Voisin, P., Canioni, P., Magistretti, P. J., \& Pellerin, L. (2003). Lactate is a preferential oxidative energy substrate over glucose for neurons in culture. Journal of Cerebral Blood Flow \& Metabolism, 23(11), 1298-1306.

Callow, M., Morton, A., \& Guppy, M. (1986). Marathon fatigue: The role of plasma fatty acids, muscle glycogen and blood glucose. European Journal of Applied Physiology, 55, 654-661.

Clemente-Suárez, V. J., \& Robles-Pérez, J. J. (2012). Respuesta orgánica en una simulación de combate. Sanidad militar, 68(2), 97-100.

Clemente, V., \& Martínez, R. (2010). Fatiga del sistema nervioso mediante umbrales flicker fusion después de una prueba de ultraresistencia por relevos de $200 \mathrm{~km}$. Cultura_Ciencia_Deporte, 13(5), 33-38.

Clemente, V. (2010). Fatiga del sistema nervioso después de una prueba de contrarreloj de 30' en cicloergómetro en ciclistas jóvenes. Motricidad. European Journal of Human Movement, 25, 197-206.

Clemente, V., Martínez, A., Muñoz, V., \& González, J. M. (2010). Fatiga del sistema nervioso central después de una prueba incremental de consumo máximo de oxígeno. Archivos de Medicina del Deporte, 137, 107-118.

Clemente, V., Muñoz, V., \& Melús, M. (2011a). Fatiga del sistema nervioso después de realizar un test de capacidad de sprints repetidos (RSA) en jugadores de futbol profesionales. Archivos de Medicina del Deporte, 143, 103-112.

Clemente, V., Muñoz, V., Ramos, D., Navarro, F., González, J., \& Juárez, D. (2011b). Analysis of selected physiological performance determinants and muscle damage in a 24-hour ultra-endurance relay race. International SportMed Journal, 12(4), 179-186.

Clemente, V., Navarro, F., \& González, J. (2011c). Changes in biochemical parameters after an ultra-endurance kayak and cycling event. International SportMed Journal, 12(1), 1-6.

Clemente-Suarez, V. J. (2014a). Changes in biochemical, strength, flexibility, and aerobic capacity parameters after a $1700 \mathrm{~km}$ ultraendurance cycling race. BioMed research international. doi:10.1155/2014/602620

Clemente-Suárez, V. J. (2014b). Psychophysiological response and energy balance during a 14-h ultraendurance mountain running event. Applied Physiology, Nutrition, and Metabolism, 40(3), 269-273. doi: 10.1139/apnm-2014-0263

Clemente-Suárez, V. J., \& Robles-Pérez, J. J. (2013b). Psycho-physiological response of soldiers in urban combat. Annals of Psychology, 29(2), 598-603. doi:10.6018/analesps.29.2.150691

Clemente-Suarez, V. J., \& Robles-Pérez, J. J. (2015). Acute effects of caffeine supplementation on cortical arousal, anxiety, physiological response and marksmanship in close quarter combat. Ergonomics, 58(11), 1842-1850. doi:10.1080/00140139.2015.1036790

Clemente-Suárez, V. J., Delgado-Moreno, R., González-Gómez, B., \& Robles-Pérez, J. J. (2015). Respuesta psicofisiológica en un salto táctico paracaidista HAHO: Caso de Estudio. Sanidad Militar, 71(3), 179-182.

Clemente-Suárez, V. J., Robles-Pérez, J. J., \& Montañez-Toledo, P. (2015). Respuesta psicofisiológica en un salto táctico paracaidista a gran altitud. A propósito de un caso. Archivos de Medicina del Deporte, 32(3), 144-148.

Costa, G. (1993). Evaluation of workload in air traffic controllers. Ergonomics, 6, 1111-1120.
Coyle, E. F. (1997). Fuels for sport performance. In D. R. Lamb \& R. Murray (Eds.), Perspectives in exercise science and sports medicine, Vol 10: Optimizing sport performance (pp. 95-137). Carmel, IN: Cooper Publishing Group.

Davis, D., Videen, J., Marino, A., Vilke, G., Dunford, J., Van Camp, S., ... Maharam, L. (2001). Exercise-associated hyponatremia in marthon runners: A two-year experience. Journal of Emergency Medicine, 21(1), 47-57.

Davis, J., \& Bailey, S. (1997). Possible mechanisms of central nervous system fatigue during exercise. Medicine \& Science in Sports \& Exercise, 29(1), 45-57.

Davis, J. M., \& Bailey, S. P. (1996). Possible mechanisms of central nervous system fatigue during exercise. Medicine and Science in Sports and Exercise, 29(1), 45-55.

Davis, J. M., \& Fitts, R. (1998). Mechanisms of muscular fatigue. In J. L. Roitman (Ed.), ACSM's resource manual for guidelines for exercise testing and prescription (pp. 182-188). Baltimore: Williams \& Wilkins.

Davranche, K., \& Pichon, A. (2005). Critical flicker frequency threshold increment after an exhausting exercise. Journal of Sport Exercise Psychology, 27, 515-520.

Douchamps-Riboux, F., Heinz, J. K., \& Douchamps, J. (1989). Arousal as a three dimensional variable: An exploratory study of behavioral changes in rowers following a marathon race. International Journal of Sport Psychology, 20(1), 31-41.

Gallego, P., Robles-Pérez, J. J., \& Clemente-Suárez, V. J. (2013). Efectos del estrés de combate en la memoria operativa del combatiente. Caso de estudio. Trabajo presentado en IX Congreso Nacional de Enfermería de la Defensa, Madrid, España.

Garcia-Roves, P., Terrados, N., \& Fernandez, F. (1998). Macronutrient intake of top level cyclists during continuos competition. International Journal of Sports Medicine, 19, 61-67.

Ghozlan, A., \& Widlocher, D. (1993). Ascending-descending threshold difference and internal subjective judgment in CFF measurements of depressed patients before and after clinical improvement. Perceptual and Motor Skills, 77, 435-439.

Glaister, M. (2005). Multiple sprint work: Physiological responses, mechanisms of fatigue and the influence of aerobic fitness. Sports Medicine, 35(9), 757-777.

Godefroy, D., Rousseu, C., Vercruyssen, F., Cremieux, J., \& Brisswalter, J. (2002). Influence of physical exercise on perceptual response in aerobically trained subjects. Perceptual Motors Skills, 94, 68-70.

Gortelmeyer, R., \& Wiemann, H. (1982). Retest reliability and construct validity critical flicker fusion frequency. Pharmacopsychiatria, 15, Suppl. 1, 24-28.

Holtzhausen, L. M., \& Noakes, T. D. (1997). Collapsed ultraendurance athlete, proposed mechanisms and an approach to management. Clinical Journal of Sport Medicine, 7(4), 292-301.

Knechtle, B., Fraire, O., Andonie, J., \& Kholer, G. (2008). Effect of a multistage ultra-endurance triathlon on body composition, World Challenge Deca Iron Triathlon 2006. British Journal of Sports Medicine, 42(2), 121-125

Lambert, E., Gibson, A., \& Noakes, T. (2005). Complex systems model of fatigue, integrative homeostatic control of peripheral physiological systems during exercise in humans. Journal of Sports Medicine, 39, 52-62.

Li, Z., Jiao, K., Chen, M., \& Wang, C. (2004). Reducing the effects of driving fatigue with magnitopuncture stimulation. Acccidental Analisis Prevention, 36, 501-505. 
Presland, J., Dowson, S., \& Cairns, S. (2005). Changes of motor drive, cortical arousal and perceived exertion following prolonged cycling to exhaustion. European Journal of Applied Physiology, 95, 42-51.

Ramos-Campo, D. J., Ávila-Gandía, V., Alacid, F., Soto-Méndez, F., Alcaraz, P. E., López-Román, F. J., ...Rubio-Arias, J. A. (2016). Muscle damage, physiological changes and energy balance in ultra-endurance mountain event athletes. Applied Physiology, Nutrition, and Metabolism, 41(8), 872-878

Saito, S. (1992). Does fatigue exist in a quantitative measurement of eye movements? Ergonomics, 35, 607-615.

Simonson, E., \& Brožek, J. (1952). Flicker fusion frequency, background and applications. Physiological Review, 32, 349-378.

Sjödin, B., \& Jacobs, I. (1981) Onset of blood lactate accumulation and marathon running performance. International Journal of Sports Medicine, 2, 23-26.

Suarez, V. C., Valdivielso, F. N., \& Rave, J. M. G. (2011). Changes in biochemical parameters after a 20-hour ultra-endurance kayak and cycling event. International SportMed Journal, 12(1), 1-6.
Suárez, V. J. C. (2011). Changes in biochemical parameters after a mountain marathon. European Journal of Human Movement, 27, 75-83.

Suárez, V. J. C., Muñoz, V., Ramos, D., Valdivielso, F. N., \& Ravé, J. M. G. (2010). Destrucción muscular, modificaciones de frecuencia cardiaca, lactato y percepción subjetiva de esfuerzo en una prueba de carrera por relevos de ultra-resistencia de 24 horas. European Journal of Human Movement, 24, 29-37.

Sulzer, N., Schwellnus, M., \& Noakes, T. (2005). Serum electrolytes in ironman triathletes with exercise-associated muscle cramping. Medicine \& Science in Sports \& Exercise, 37(7), 1081-1085.

Tomporowski, P. (2003). Effects of acute bouts of exercise on cognition. Acta Psychologycal, 112, 297-324.

Whiting, P., Maughan, R., \& Miller, J. (1984). Dehydration and serum biochemical changes in marathon runners. European Journal of Applied Physiology, 52, 183-187. 